\title{
Effect of rearing system and season on behaviour, productive performance and carcass quality of rabbit: A review
}

\author{
Karim El-Sabrout
}

El-Sabrout K (Corresponding author)

Department of Poultry Production, Faculty of Agriculture (El-

email: kareem.badr@alexu.edu.eg

Shatby), University of Alexandria, Alexandria, Egypt.

Received: April 22, 2018 - Revised: June 04, 2018 • Accepted: June 04, 2018

\begin{abstract}
Nowadays, researchers and even consumers need more information on the effect of different rearing systems and seasons not only on the animal behaviour and production but also on carcass quality. Understanding more about how the rearing system and season can influence behaviour, production and carcass traits of rabbit is extremely important. This current review proposes best investigation to cover these points. In many countries like in Spain, Italy and Egypt, rabbit (Oryctolagus cuniculus) plays an important role in meat production. Rabbit rearing systems as a part of animal welfare have been the focus of scientific research in order to improve well-being for high-quality products. Rabbits have specific behavioural needs and are able to change their behaviour to adapt the changes happened in the surrounding environment. Among these changes, it was the season's variables: high ambient temperature, humidity and ventilation that can affect the animal performance.
\end{abstract}

Keywords: behaviour, carcass quality, production, rabbit, rearing system, season

\section{Introduction}

Rabbit production has an important role in bridging shortage of food in many countries (Khalil et al 2016). Rabbit meat has several advantages including high protein content and low cholesterol content (Hanaa et al 2014). The quality attributes of food products including rabbit meat have been attracting an increasing interest in recent years. The meat products from ecological rearing are characterized by a higher nutritive quality, and better taste (Horsted et al 2010). There is always a relationship between meat quality and animal welfare.

Animal welfare is about life quality. It is clear that the characteristics of the animal are concerned with the effects of all aspects of genotype and environment conditions (Duncan 2002). The concept of good welfare is provided when the individual is able to adapt to or to cope with the constraints of housing and management conditions to which it is exposed to
(Duncan 2002). The safe production taking animal welfare and environmental conditions into account is gaining importance worldwide. The demerit welfare is usually associated with a reduction in productivity (Jones et al 2007). According to the rabbit welfare aspects are keeping the animals in larger groups on deep litter. The behavioural measures are often the starting point for assessing an animal's response to its environment (Dawkins 2003).

Simply, the animal behaviour is an animal reaction to the environment changes and it depends on both genetic characteristics and non-genetic factors (Manteuffel 2002). Animal behaviour is affected by the environment. Therefore, knowing how the environment affects animals allows us to identify and to quantify welfare. Environmental enrichment can foster and encourage natural behaviours and create a greater number of behavioural opportunities (Mellen and MacPhee 2001). All animals possess a range of behavioural expectations regarding their surroundings. Environmental conditions are extremely important to rabbit rearing and affect its behaviour directly. According to Ferrante et al (2001), the animal behaviour depends on the rearing environment. Few are known about the behavioural activities of rabbit (ElSabrout 2018). The study of rabbit behaviour is necessary to understand more about the important requirements of intensive rearing housing conditions. Chu et al (2004) found that rabbits differ from other livestock with specific behaviour which assessed on the basis of the behaviour of the wild animal.

Raising systems have remarkable effects on behaviour and the productive traits of poultry. Such systems coupled with high standards of animal welfare can provide special animal products related to a greater quality and security of meat which is the increasing preference of consumers in many countries (Fanatico et al 2006). Access to free-range can improve welfare and allow animal to show complete sunbathing behaviour (Gonçalves et al 2017). In agreement, Ruis and Coenen (2004) concluded that an outdoor also improves welfare. 
Study of genetic and non-genetic factors affecting productive traits in rabbits is important to be studied. Season as one of non-genetic factors can influence the reproductive and production performance of rabbit (Kumar et al 2013). The maintenance of sexual desire behaviour of rabbit is controlled by a complicated system that includes hormones which affected by season (El-Sabrout 2017). The behavioural changes are the first animal response to attempt to regulate internal temperature as a function of environment, and this response can be used to predict welfare levels. The genetic variation found in domestic rabbit lines allows developing new characteristics in response to changes in the environment (El-Sabrout and Aggag 2015). As rabbit behaviour is affected by season, season also can affect the weight gain. McNitt and Lukefahr (1993) reported a significant impact of the season on the growth of rabbits, with the lowest gain in summer. Moreover, Marai et al (2001) found that feed intake behaviour and daily weight gain of growing rabbits decreased with heat stress. In addition, Bhatt et al (2002) obtained the most successful results for rabbit reproduction during the winter season.

Animal meat quality is generally concerned as a very complex issue that can be looked at from several points of view. In terms of meat processing industry and consumers' interests, fattened chicks should be characterized by good dressing percentage, desired conformation, as much meat on the carcass as possible, optimal distribution of fat tissues, appropriate skin color and least damage possible due to fattening, loading and unloading. With respect to that, the proportions of basic carcass parts, the presence of certain tissues in them, as well as the chemical composition of the muscle tissue, are regarded as vital parameters determining animal meat quality (Holcman et al 2003; Ristić 2003). Among numerous non-genetic factors that may have a considerable effect on some meat quality traits, a rearing system has been recognized over the past years by a large number of authors as being particularly important (Hellmeister et al 2003; Ristić 2003).

Therefore, the present review was undertaken to study the effect of rearing system and season on the behaviour, production and carcass traits of the rabbit.

\section{Rearing systems}

The interest in obtaining rabbit meat from less intensive rearing systems has increased in the last decade. Rabbit welfare can be safeguarded by different management systems. The animal welfare is necessary to evaluate alternative rearing systems for livestock in order to improve well-being. The rearing systems can affect reproductive behaviour, body weight and carcass quality (Maertens and Van Oeckel 2001; Marai and Rashwan 2003; Pla 2008). The concern regarding conventional cages is that behavioural restriction is inherent to the system and rabbits are prevented from expressing highly motivated behaviours. Non-cage systems enable the expression of a more diverse array of ancestral behaviour patterns, with the greatest behavioral diversity occurring in free-range systems. The conventional production systems have the potential to influence animal welfare in both positive and negative ways. The cage raising system represents an appropriate technology commonly adopted exactly in tropical climates. Unfortunately, such system restricts the rabbits to protect themselves from the unfavourable environment and compels them to remain exposed without any defense to the noxious effect of heat (Finzi et al 1996). The intensive rearing system for rabbits is based on group wire cages, which are located inside buildings (Hernandez and Gondret 2006). The traditional breeding cage can produce stress in animals (Drescher 1992), which is reflected on adaptive behaviour aspects (Wiepkema and Koolhas 1993).

Particularly, Drescher (1992) clarified that keeping rabbits singly in cages is not compatible with the demand of housing with respect to animal welfare, since the singly caged rabbit has no social contact to non-specific necessary as natural external stimulus and has no conditions for suitable locomotion. This may be the reason in that caged rabbits show nervous behaviour, altered forms of movement and low relaxed resting behaviour, because of the narrowness of the cage and the wire floor. Conventional confined systems can lead to domestic bird stress (Jones and Mills 1999), resulting in physiological and behavioural responses (Marin et al 2001) and poor performance (Mendl 1999). According to Ferrante et al (2001), animal behavior depends on the rearing environment, whereas Jones et al (2007) reported that improvement in ambient conditions might result in benefits. The consumers recently interest in product's quality derived from free-range and organic production systems.

\section{Behaviour activities}

The rearing system of rabbits is related to behavioural, hygienic, environ-mental and welfare aspects. Verga et al (2004) reported that animal behaviour is affected by type of cages. Useful information on behaviour of rabbit may be obtained by observing its response during the new environmental conditions. Several studies revealed the effect of group size and density on behaviour and productive performance of rabbits. Although the results often differ and may be confused by other factors of variability. Rabbits raised in larger groups rested less and were more active. They spent more time moving around and in aggressive behaviours. Aggressive behaviour is one of the main problems of housing rabbits in large groups. Upon reaching sexual maturity, the number of aggressive conflicts increases and causes more or less serious injuries to different parts of the body. 
The extensive rearing systems provide animals with more space and freedom of movement. So, it permits them a broad range of behaviour patterns and better satisfies the natural (Morisse et al 1999). Pinheiro and Mourao (2007) reported that rabbit pasture pen housing systems provide more freedom behaviours than conventional cages. Lebas (2001) found that housing systems with floor pens or colony cages seem to reduce stress and aggressive behaviour of animals, but it increases mortality and decrease growth rates, feed intake, feed efficiency, and sometimes meat quality (Combes et al 2003; McNitt et al 2003). Due to the numerous variables involved like group size and stocking density, the previous studies on extensive housing systems have often been inconclusive.

In addition, Jekkel et al (2010) revealed a reduction in the growth performance of rabbits housed in conventional systems compared with housing in parks. Maertens and Van Oeckel (2001) reported that the reduction in feed intake in the outdoor rearing systems plays an effective role in lowering weight gains. The open-air pens increase the energy maintenance requirements of rabbits and provide more space for animal movement (Maertens and Van Oeckel 2001). The increased energy requirements combined with the decrease in feed intake might result in lower growth.

\section{Productive performance}

According to Dal Bosco et al (2001), the rearing system affects growth and body weight. The influence of rearing system on production traits has been studied in many researches. Some has suggested that free-range rearing results in lower body weight of rabbits as compared to indoor rearing. Canquil et al (2001) reported that cage-housed rabbits were higher body weight then pen housed. The rabbits raised in the cages had a significantly greater slaughter weight than in the open-air. Consequently, the feed intake and the weight gain were reduced (McNitt et al 2003). Mirabito (2005a and 2005b) compared three housing systems for reproducing does: conventional individual cages, modified cages for two does, and pens with net floors for four does. Reproductive performance was similar among groups. The fast-growing hybrids attain higher body weight under free-range rearing conditions as compared to slow and moderately fast growing hybrids (Fanatico et al 2005).

The mortality is an important parameter in rabbit production. It requires consideration of overall environmental conditions. Mortality in indoor rearing systems is induced by temperature, humidity, feed supply and stocking density (Sorensen et al 2000; Heier et al 2002). The mortality of rabbits of poor growth and lower body weight was higher in the pen-housed group. Sossidou et al (2011) reported the main cause of death under these production systems to be higher exposure to diseases and parasites in the outdoor environment.
Carcass quality

The recent interest in the rabbit rearing system affects due to improve well-being for high-quality products. Customers who prefer rabbit products have interested also with the high-quality carcass derived from the higher standards of animal welfare. According to Dal Bosco et al (2002) the housing system affects some carcass parameters and sometimes the meat quality. However, with the increasing customer demand for high-quality animal products (Keskin et al 2012) mainly home-made products or meat from alternative rearing systems complying with the conditions of welfare become still more required. The housing system is one of the factors, which moderately affect rabbit carcass and meat quality (Dalle Zotte 2002). As animal movement increases the number of mitochondria in $\alpha \mathrm{W}$ fibres also increases, converting their predominant glycolytic energy metabolism into oxidative energy metabolism and then, part of the $\alpha \mathrm{W}$ fibers turn into $\alpha \mathrm{R}$ fibers, richer in myoglobin. In contrast, reduced movements increase the muscle glycogen storage used for the anaerobic energy metabolism (Ouhayoun 1998; Gregory 2003). The higher fat content might be related to the productive performance of outdoor rabbits that showed significantly higher live weights resulting in higher reference carcass (D'Agata et al 2007). It was probably due to the better environmental and consequently healthy conditions induced by this housing system that could have increased the animal welfare (Cozzi et al 2000).

The chemical composition of rabbit meat was different than other livestock. The protein and fat contents show strong links with rearing systems Castelini et al (2008). Sirri et al (2010) found that genotype had the priority affecting chemical composition and quality of meat in non-intensive rearing systems. In agreement, Meluzzi et al (2009) observed that rearing system is very important parameter that affects carcass and meat quality.

The dressing percentage is one of the most important characteristics of rabbit's carcass (Combes et al 2010). Although the dressing percentage in the caged rabbits was similar to that of the open-air rabbits, the caged rabbits had higher slaughter weight. The open-air rabbits had a higher reference carcass percentage, which is probably due to the decreased viscera weight, although this difference was not significant. Also, the dissectible fat percent in the carcasses of the open-air was significantly lower than that observed in the caged rabbits. Dal Bosco et al (2000) found a lower lipid percent in the carcasses of open-air rabbits than in caged rabbits. Reductions in the energy available for growth and fat deposition likely contributed to this effect. Xiccato et al (1999) found that dressing percentage is affected by stocking density. Moreover, the heavier rabbits have a higher dressing out percentage (Milisits et al 2000). In open-air, the carcass of rabbits had lower lightness color and the meat had a higher 
redness color than those kept in cages. The increase in the redness of the open-air rabbit meat can be explained by the fact that exercise increases the oxidative capacity of the muscle, which increases the proportion of oxidative myofibers and the myoglobin content (Monin and Ouali 1991). In agreement, Pla (2008) observed also increases in meat redness.

Smith and Teeter (1987) reported that the outside air temperature exceeds the optimum range can affect carcass traits and decrease the dressing percentage. This finding is important for animal raise in free-range rearing systems where the temperature cannot be controlled. The variation in rabbit meat quality between alternative rearing systems was clear (Castellini et al 2008). Fattening rabbits were kept under markedly different conditions: cages of different size were used with different stocking densities or group sizes. The profitability of rabbit production is therefore largely determined by the possibility of increasing the proportion of prime parts in the carcass and by reducing fat. However, the standardization of quality rabbits industry is falling behind because of the knowledge gap of proper rearing conditions and management.

\section{Seasons}

Season plays a major role in the animal welfare by many factors including temperature, relative humidity, and lighting (Holik 2015). Studying factors that can affect the animal behaviour is very important. The animal behaviour can impact its productive traits. Seasonal variation on litter traits due to kindling season is a reflection of differences in seasonal climate conditions in geographical location of the rabbitry.

\section{Behaviour activities}

Among the season components that may impose influence on the animal are ambient temperature, humidity, air movement, and photoperiod. Optimal climatic conditions for rabbits would be: air temperature 13 o to $20^{\circ} \mathrm{C}$ (average $15^{\circ} \mathrm{C}$ ), relative humidity 55 to $65 \%$ (average $60 \%$ ), wind velocity 5 to $18 \mathrm{~km} / \mathrm{h}$, ventilation capacity of at least $0.17 \mathrm{~m} 3 /$ minute $(6$ $\mathrm{cm})$ air flow per rabbit housed and a moderate level of sunshine. Generally, when analyzing seasonal effects, temperature and light are considered in Europe, although temperature seems to be not directly involved (Lebas et al 1986). In tropical climates, temperature seems to be the dominant factor, but variations in length of daylight cannot be excluded. In sub-tropical climate (such as in Egypt), the ambient temperature, relative humidity, and diurnal light seemed to be involved (Habeeb et al 1993 and Marai et al 1996), although feasibility of the use of certain light regime in commercial rabbit production, is not clear (Marai et al 2004).
As regards sexual behaviour, wild rabbits mate almost exclusively in the first hours after kindling and reproductive activity usually increases with increasing daylight in spring. Reproductive performance remains high all year round thanks to a constant photoperiod of 14-16 hours of light, while the use of artificial insemination prevents the expression of premating behaviour, a characteristic of wild rabbits still present in domestic rabbits. The results of El-Sabrout and Shebl (2015) showed that the rabbits raised in the winter had significant higher feeding and sexual desire than rabbits raised in summer. Rabbits tend to mate in winter than in summer season. Raising rabbits during winter (December-February) is better than summer season (June-August) in terms of both behaviour and productive efficiency. Season plays a significant role in relation to the reproduction of rabbit does (Tuma et al 2010).

\section{Productive performance}

El-Sabrout and Shebl (2015) showed insignificant effect of season on rabbit's litter size. In agreement Tawfeek (1995) reported insignificant effect of season of kindling on litter size of New Zealand and Bauscat rabbits. Litter mortality is a good indicator for mothering ability (Poornima et al 2002). El-Maghawry (1997) stated that mortality rate of young rabbits controlled by both genetic and non-genetic factors like season. In the present study, the mortality rate was lower in winter compared with summer season. Marai et al (1996) indicated that rabbit mortality was lower in winter than in summer season due to heat stress effect on rabbits. Litter size and weight are regarded as the best estimates of number and weight of young produced by the doe. These productive traits reflect the contribution of maternal behaviour, milk production, growth and survival (El-Maghraby et al 2007).

The breeding season had significant effect on the litter body weight. A rabbit born during the winter season attained a significantly higher body weight than other born during the summer season (Ghosh et al 2008). In addition, season had significant effect on milk yield of doe. El-Sabrout and Shebl (2015) found that litter weight at marketing age was significantly higher in winter than in summer. The results of milk yield showed that it was higher in winter than summer. Moreover, the results of litter size showed insignificant difference at all. The mortality rate was significantly lower in winter than in summer. Generally, the peak of milk production is incidence at approximately 21 days after delivery in rabbits. Marai et al (1996) found that summer season could decrease dams' milk production as a result of the general reduction of metabolic activity. Milk yield of doe was decreased in summer season as a result of feeding reduction due to high temperature. Kumar et al (2013) reported that summer season could be attributed to stress factors affecting feed intake. 


\section{Carcass quality}

Rabbit meat has long been known in Mediterranean countries. The consumption trend depends on the consumer's interest in products obtained by different rearing systems that should assure higher standards of animal welfare along with high meat quality. The season can affect the carcass quality (physical and chemical characteristics) of animal (D'Alessandro et al 2012). Considering the effect of the season, the carcass weights of the lambs were heavier in the spring in comparison with the winter. Furthermore, the fat percentage was affected by the season (D'Alessandro et al 2012). The age and the slaughter season influenced the majority of the measurements of the lamb carcasses.

According to Babicz et al (2008) the carcass and meat quality may be varied according to the year of slaughter. Antosik et al (2010) noted that the level of the slaughter characteristics may also vary due to time of year. By analyzing the impact of the seasons on the investigated traits, it was found that growing-finishing pigs slaughtered during winter and spring had the highest carcass weight, and backfat thickness, which was found to be highly significant. The results of the impact of the seasons on the value of the carcass and meat quality are in accordance with the study of Antosik et al (2010). The season plays a major role on productive and carcass quality of the rabbit (Dalle Zotte 2002). The increase of environmental temperature over the thermo-neutrality value reduces rabbit feed intake and consequently, growth rate resulting in lower market weight at slaughter age. Seasonal conditions can affect carcass quality and negatively the economics of producers and processors.

\section{Final Considerations}

Rearing system and season as non-genetic factors affect directly the welfare of the rabbit. Different rearing system and season variation can affect the rabbit behavioural, productive performance and finally the carcass quality. An unsuitable environment may cause abnormal behavioural responses and reduced productivity.

\section{Conflict of interest}

The author declares that there is no known conflict of interest associated with this publication.

\section{References}

Antosik K, Koćwin-Podsiadła M, Kudelska A (2010) Związek mięsności z cechami jakości tuszy tuczników pogłowia masowego ubijanych w różnych sezonach. Materiały konferencyjne LXXV Zjazd PTZ, Olsztyn 2010, 65.

Babicz M, Kamyk P, Stasiak A (2008) Evaluation of carcass and meat quality of growing-finishing pigs slaughtered in the
Lubelszczyzna region in 2005-2006. Ann. Univ. Mariae CurieSkłodowska, sect. EE, 26:17-23.

Bhatt RS, Sharma SR, Singh U, Kumar D, Bhasin V (2002) Effect of different season on the performance of grey giant rabbits under subtemperate Himalayan conditions. Asian-Australian Journal of Animal Sciences 15:812-820.

Canquil L, Combes N, Jehl N, Darche B, Lebas F (2001) Caractérisation physico-chimique et rhéologique de la viande de lapin. Application p la comparison de lapins label et standard. $9^{\text {ème }}$ Journal Rechearche Cunicole, Paris, 11-14.

Castellini C, Berri C, Le Bihan-Duval E, Martino G (2008) Qualitative attributesand consumer perception of organic and freerange poultry meat. World's Poultry Science Journal 65:120-135.

Chu L, Garner JP, Mench JA (2004) A behavioral comparison of New Zealand White rabbits (Oryctolagus cuniculus) housed individually or in pairs in conventional laboratory cages. Apply Animimal Behaviour Science 85:121-139.

Combes S, Lebas F (2003) Les modes de logement du lapin en engraissment: influence sur les qualités des carcasses et des viandes. In Proc.: 10èmes Journées Recherche Cunicole, Paris, France, 185200.

Combes S, Postollec G, Cauquil L, Gidenne T, Combes S, Postollec G, Cauquil L, Gidenne T (2010) Influence of cage or pen housing on carcass traits and meat quality of rabbit. Animal 4:295-302.

Cozzi G, Gottardo F, Andreoli D, Andrighetto I, Mattiello S, Ferrante $\mathrm{V}$, et al. (2000) Somministrazione di un mangime solido a vitelli a carne Bianca stabulati in gabbia individuale o in box di gruppo. 1. Prestazioni produttive equalità della carne. Zootecnica e Nutrizione Animale 26:233-242.

D'Alessandro AG, Maiorano G, Kowaliszyn B, Loiudice P, Martemucci G (2012) How the nutritional value and consumer acceptability ofsuckling lambs meat is affected by the maternal feeding system. Small Ruminant Research 106:83-91.

D'Agata EMC, Magal P, Olivier D, Ruan S, Webb GF (2007) Modeling antibiotic resistance in hospitals: The impact of minimizing treatment duration. Journal Theorology Biology 249:487-499.

Dal Bosco A, Castellini C, Muanai C (2001) Effet du mode d'élevage (cage ou parc) sur l'évolution post mortem du $\mathrm{pH}$ et sur les caractéres qualitatifs de la viande de lapin. $6^{\text {éme }}$ Journal Rechearche Cunicole, Paris, 35-38.

Dal Bosco A, Castellini C, Mugnai C (2002) Rearing rabbits on wire net floor or straw litter: Behaviour, growth and meat qualitative traits. Livestock Production Science 75:149-156.

Dal Bosco A, Castellini C, Bernardini M (2000) Productive performance and carcass and meat characteristics of cage- or penraised rabbits. World Rabbit Science 8:579-583.

Dalle Zotte A (2002) Perception of rabbit meat quality and major factors influencing the rabbit carcass and meat quality. Livestock Production Science 75:11-32.

Dalle Zotte A, Paci G, Mirisola M, Serva L, Riovanto R, Berzaghi P (2008) Impiego della spettroscopia NIR per la stima della composizione chimica ed acidica della carne di coniglio e per discriminare l'allevamento Outdoor da quello Indoor. In Proceedings $3^{\text {rd }}$ Symposium NIR Italia, Verona, Italy.

Dawkins MS (2003) Behaviour as a tool in the assessment of animal welfare. Zoology 106:383-387. 
Drescher B (1992) Housing of rabbits to animal welfare. Applied Rabbit Research 15:678-683.

Duncan IJH (2002) Gordon memorial lecture. Poultry welfare: science or subjectivity? British Poultry Science 43:643-652.

El-Maghawry AM (1997) Evaluation of the performance of three foreign rabbit breeds under Egyptian conditions. Egyptian Journal Rabbit Science 7:95-106.

El-Maghraby MMA, Mahrous OE (2007) Influence of some preweaning factors and cross fostering on market traits of New Zealand White rabbits. Benha Veterinary Medical Journal 181:269-285.

El-Sabrout K (2018) Does the blindness affect the behavioural activities of rabbit? Journal of Animal Behaviour and Biometeorology 6:6-8.

El-Sabrout K, Aggag SA (2015) Use of inter simple sequence repeats and protein markers in assessing genetic diversity and relationships among four rabbit genotypes. World Rabbit Science 23:283-288.

El-Sabrout K, Shebl MK (2015) Effect of Line and Season on Productive Performance of Rabbits. International Journal of Animal Biology 1: 182-186.

El-Sabrout K (2017) Associations between single-nucleotide polymorphisms of melanocortin gene and sexual desire behaviour in rabbit (Oryctolagus cuniculus). Journal of Veterinary Behavior 19:69-71.

Fanatico AC, Cavitt LC, Pillai PB, Emmert JL, Owens CM (2005) Evaluation of slow-growing broiler genotypes grown with and without outdoor access: meat quality. Poultry Science 84:1785-1790.

Fanatico AC, Pillai PB, Cavitt LC, Emmert JL, Meullenet JF, Owens CM (2006) Evaluation of slower-growing broiler genotypes grown with and without outdoor access: sensory attributes. Poultry Science 85:337-343.

Ferrante V, Verga M, Mangiagalli MG, Carenzi C (2001) Behaviour reactions, semen quality and testosterone levels in cocks: genetic implications. Animal Welfare 10:269-279.

Finzi A, Margarit R, Calabrese A (1996) A two-floor cage for rabbit welfare. In Proc.: 6th World Rabbit Congress, Toulouse, France, 423424.

Ghosh SK, Das A, Bujarbaruah KM, Das A, Dhiman KR, Singh NP (2008) Effect of breed and season on rabbit production under subtropical climate. World Rabbit Science 16:29-33.

Gonçalves S, Ferreira R, Pereira I, Oliveira C, Amaral P, Garbossa C, Fonseca L (2017) Behavioral and physiological responses of different genetic lines of free-range broiler raised on a semi-intensive system. Journal of Animal Behaviour and Biometeorology 5:112117.

Gregory NG (2003) Animal welfare and meat science. USA: CABI Publishing Cambridge.

Habeeb AA, Aboul-Naga AI, Yousef HM (1993) Influence of exposure to high temperature on daily gain, feed efficiency and blood components of growing male Californian rabbits. Egyptian Journal of Rabbit Science 3:73-80.

Hanaa A, El-Raffa A, Shebl MK, El-Delebshany A, El-Sayed N (2014) Genetic evaluation of some economic traits in a maternal line of rabbits. Egyptian Journal of Poultry Science 34:85-98.

Heier BT, Hogasen HR, Jarp J (2002) Factors associated with mortality in Norwegian broiler flocks. Preventive Veterinary Medicine 53:147-158.
Hellmeister Filho P, Machado Menten JF, Neves da Silva MA, Coelho AAD, Savino VJM (2003) Efeito de genotipo e do sistema de criacao sorbe o desempenho de frangos tipo caipira. Revista Brasileira de Zootecnia 32:1883-1889.

Hernandez P, Gondret F (2006) Rabbit Meat Quality. In: Maertens L., Coudert P. (Eds.). Recent Advances in Rabbit Sciences. ILVO, Belgium, 269-290.

Holcman AR, Vadnjal B, Žledner Stibilj V (2003) Chemical composition of chicken meat from free range and extensive indoor rearing. Archiv fur Geflugelkunde 67:120-124.

Holik V (2015) Management of laying hens under tropical conditions begins during the rearing period. Lohmann Information, 50:16- 23.

Horsted K, Allesen-Holm BH, Hermansen JE (2010) The effect of breed and feed-type on the sensory profi le on breast meat in male broilers reared in an organic free-range system. British Poultry Science 4:515-524.

Jekkel G, Gabor MilisitsG, Nagy I (2010) Effect of alternative rearing methods on the behaviour and on the growth and slaughter traits of growing rabbits. Arch Tierz 53:205-215.

Jones RB, Mills AD (1999) Divergent selection for social reinstatement behaviour in Japanese quail: effects on sociality and social discrimination. Poultry and Avian Biology Reviews 10:213223.

Jones T, Feber R, Hemery G, Cook P, James K, Lamberth C, Dawkins M (2007) Welfare and environmental benefits of integrating commercially viable free-range broiler chickens into newly planted woodland. A UK case study. Agricultural systems 94:177-188.

Keskin S, Kor A, Karaca S (2012) Evaluation of sensory characteristics of sheep and goat meat by Procrustes Analysis. Czech Journal of Animal Science 57:516-521.

Khalil MH, Shebl MK, Kosba MA, El-Sabrout K, Zaki N (2016) Estimate the contribution of incubation parameters influence egg hatchability using multiple linear regression analysis. Veterinary World 9:806-810.

Kumar D, Risam KS, Bhatt RS, Singh U (2013) Reproductive performance of different breeds of broiler rabbits under subtemperate climatic conditions. World Rabbit Science 21:169-173.

Lebas F (2001) Fattening farms: advantages and disadvantages. Cuniculture 28:163-168.

Lebas F, Coudert P, Rouvier R, De Rockambeau H (1986) The Rabbit: Husbandry, Health and Production. F.A.O., U.N, Rome, Italy.

Maertens L, Van Oeckel MJ (2001) Effet du logement en cage on en parc et de son enrichment sur les performances et la couleur de la viande des lapins. Proc. $9^{\text {émes }}$ Journal of Recherche Cunicole, Paris, France, pp 31-34.

Manteuffel G (2002) Central nervous regulation of the hypothalamicpituitary-adrenal axis and its impact on fertility, immunity, metabolism and animal welfare - a review. Archiv für Tierzucht Dummerstorf 45:575-595.

Marai FM, Rashwan AA (2003) Rabbits behaviour under modern commercial production conditions - a review. Arch Tierz 46:357376.

Marai IFM, Ayytat MS, Abd El-Monem UM (2001) Growth performance and reproductive trans at first parity of New Zealand White female rabbits as affected by heat stress and its alleviation under Egyptian conditions. Tropical Animal Health and Production, 33:451-462. 
Marai IFM, Rashwan AA (2004) Rabbit behavioural response to climatic and managerial conditions - a review. Archiv fur Tierzucht 47:469-482.

Marai IFM, Ayyat MS, Gaber HA, Abdel-Moneim UM (1996) Effect of heat stress anti amelioration on reproductive performance of New Zealand White adult female and male rabbits, under Egyptian conditions. In Proc.: $6^{\text {th }}$ World Rabbit Congress, Toulouse, France. 2:197-202.

McNitt JI, Lukefahr SD (1993) Breed and environmental-effects on postweaning growth of rabbits. Journal of Animal Science 71:19962005.

McNitt J, Way R, Way M, Forrester-Anderson I (2003) Growth of fryers reared and (or) finished using controlled grazing in movable pens. World Rabbit Science 11:189-198.

Mellen J, MacPhee MS (2001) Philosophy of environmental enrichment: past, present, and future. Zoology Biology 20:211-226.

Meluzzi A, Sirri F, Castellini C, Roncarati A, Melotti P, Franchini A (2009) Infuence of genotype and feeding on chemical composition of organic chicken meat.. Italian Journal of Animal Science 8:766-768.

Mendl M (1999) Performing under pressure: stress and cognitive function. Applied Animal Behaviour Science 65:221-244.

Milisits G, Romvári R, Szendrő Zs, Masoero G, Bergoglio G (2000) The effect of age and weight on slaughter traits and meat composition of Pannon White growing rabbits. World Rabbit Science 8:629-636.

Mirabito L, Galliot P, Souchet C, Dumont F, Thomeret F (2005a) Logement collectif des lapines reproductrices: Conséquences zootechniques. Proc. $11^{\text {èmes }}$ Journées Recherche Cunicole, Paris, France, 53-56.

Mirabito L, Dumont F, Galliot P, Souchet C (2005b) Logement collectif des lapines reproductrices: Conséquences sur le

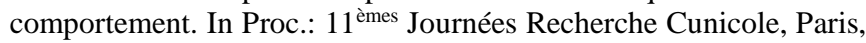
France, 57-60.

Monin G, Ouali A (1991) Muscle differentiation and meat quality. In: Lawrie R (ed.) Developments in meat science. Elsevier Applied Science, London, UK/New York, USA, 89-157.

Morisse JP, Boilletot E, Martrenchar A (1999) Preference testing in intensively kept meat production rabbits for straw on wire grid floor. Applied Animimal Behaviour Science 64:71-80.

Ouhayoun J (1998) Influence of the diet on rabbit meat quality. In C. De Blas \& J. Wisemann (Eds.), The nutrition of the rabbit. Wallingford Oxon, UK: CABI Publishing.

Pinheiro V, Mourao JL (2007) Alternative production systems for fattening rabbits. In: Proc Congr Iberico de Cunicultura da APEZ e ASESCU, Vila Real, Portugal, 163-173.

Pla M (2008) A comparison of the carcass traits and meat quality of conventionally and organically produced rabbits. Livestock Production Science 115:1-12.

Poornima K, Ramesh Z, Gupta B, Narasiniha G, Satyanarayana A (2002) Genetic study on pre-weaning body weights and growth rates in Caledonian White rabbits. Indian Journal of Animal Science 72:601-603.

Ristić M (2003) Fleischqualitat von broilern der okologishen produktion. Institute for Animal Husbandry Belgrade-Zemun. Biotechnology Animal Husbandry 19:335-343.

Ruis M, Coenen E (2004) A group-housing system for rabbit does in commercial production: a new approach. World Rabbit Science 13:200-201.
Sirri F, Castelini C, Roncarati A, Franchini A, Meluzzi A (2010) Effect of feeding and genotype on the lipid profile of organic chicken meat. European Journal of Lipid Science Technology 112:994-1002.

Smith MO, Teeter RG (1987) Influence on feed intake and ambient temperature stress on the relative yield of broilers parts. Nutritional Reports International 35:299-306.

Sorensen P, Su G, Kestin SC (2000) Effects of age and stocking density on leg weakness in broiler chickens. Poultry Science 79:864870.

Sossidou EN, Dal Bosco A, Elson HA, Fontes CM (2011) Pasturebased system for poultry production: implications and perspectives. World's Poultry Science Journal 67:47-58.

Tawfeek MI (1995) Performance of doe rabbits and their young's as affected by remating interval, litter size at birth and month of kindling in New Zealand White and Bauscat purebreds, under Egyptian conditions. Egyptian Journal of Rabbit Science 5:101-115.

Tuma J, Tumova E, Valasek V (2010) The effect of season and parity order on fertility of rabbit does and kit growth. Czech Journal of Animal Science 55:330-336.

Verga M, Zingarelli I, Heinzl E, Ferrante V, Martino PA, Luzi F (2004) Effect of housing and environmental enrichment on performance and behaviour in fattening rabbits. World Rabbit Science 13:139-140.

Wiepkema PR, Koolhaas JM (1993) Stress and animal welfare. Animal Welfare 2:195-218.

Xiccato G, Verga M, Trocino A, Ferrante V, Queaque PI, Sartori A (1999) Influence de l'effectif et de la densité par cage sur les performances productives, la qualité bouchère et le comportement chez le lapin. In Proceedings $8^{\text {émes }}$ Journées Recherche Cunicole. Paris, France. pp 56-63. 